UDC 677.055.6

V.V. Chaban, Dr.Eng., Professor,

B.F. Pipa, Dr.Eng., Professor,

Kyiv National University of Technologies and Design

\title{
THE CALCULATION OF WARPING SPOOLS OF WARP-KNITTING MACHINES
}

Introduction. One of the main ways for increasing warp-knitting machines efficiency is to reduce their downtime due to base thread recharge and to reduce dynamic loads caused by an unstable regime (starting, braking, etc.) [1...15]. That approach is implemented through increasing the section warp beams capacity determined by the amount of threads wound on the warp beam, as well as through the development of devices reducing the machinery mechanisms' dynamic loads.

Literature review. Analysis of latest studies [7, 8, 12, 13] shows that most types of warping machines are equipped with standardized warping bobbins and therefore must allow winding the entire range of threads that can be processed. However, the practical experience shows that in some cases (such as when warping synthetic filament yarn of high numbers of synthetic zero-twist yarns) the bobbin destruction caused by the filaments pressure takes place. Therefore, the said yarns warping, the standardized bobbin capacity is not fully used. Despite the urgency of the problem in enhancing warping bobbins' efficiency, we still lack for rational methods of warping spools calculation.

Aim of the Research. Given the urgency of warp knitting machines efficiency enhancing problem at the expense of warping spools increased efficiency, this research has been purposed to develop a method for calculating the sectional warping bobbins of warp-knitting machines. In solving this problem we used modern methods of theoretical studies based on the theory of elasticity and strength of mechanical systems.

Main Body. The warping bobbins destruction (Fig. 1) does clearly indicate that while warping several conditions may occur creating a mode when the spools' strength does not correspond to the loads charged by threads warped.
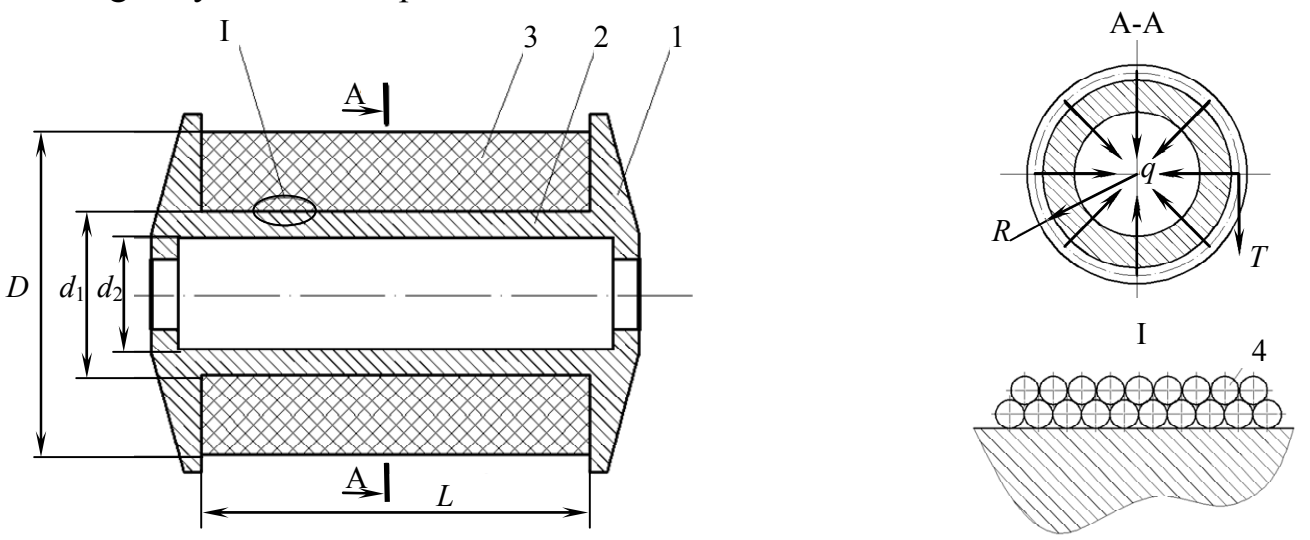

Fig. 1. Warp-knitting machines' warping spool and its design scheme:1 - bobbin head; 2 - bobbin shaft; 3 thread warping; 4 - synthetic thread sectional cut

Given that the said loads have not yet been studied, complicated are both the standard bobbins operation and the substantiation for designing the increased capacity new bobbins. Therefore, the problem of determining the loads applied by the wound yarn acting onto warping bobbins' structural elements (buttes and shaft) is very actual one.

DOI 10.15276/opu.2.44.2014.13

(c) V.V. Chaban, B.F. Pipa, 2014 
Considering the warping spools operation experience, it can be assumed that the greatest value of these loads is achieved when synthetic filament yarn processing, so we decided to investigate the relationship between these threads' parameters and their tension when warping from one hand, and from another, the warping bobbins' size on one side and the load applied to their structural elements on the other. The paper presents the bobbin shaft durability calculation and recommendations on reducing the studied loads.

Currently, the most widespread warping bobbins type is this one where the buttes' inner surface is perpendicular to the longitudinal axis of the bobbin shaft.

Let we assume that the spool bears some synthetic filament yarns (hereinafter yarn) warped at some tension $T$; the yarn twist is small, or equal to zero, and all filaments have the same length at a constant circular cross section. We assume the longitudinal filaments yarns to be arranged at the bobbin cross section as shown at Fig. 1. Let suppose that after warping the filaments have the same tension degree and are arranged in concentric layers of closed circles lying within planes perpendicular to the bobbin axis.

In this case, the bobbin butts are influenced with total force $Q$ acting on the part of the fibers that are in contact with the butts. Let we denote $Q_{i}$ the force applied to the butt by filaments lying in the $i^{\text {th }}$ layer counting from the warping surface.

Now we consider the equilibrium of this fiber element disposed between adjacent longitudinal sections of the bobbin, the angle between which is equal to $d \varphi$. Here we can neglect the element-tobutt and the element-to-contacting filaments friction. Then the element is subjected to the reaction $d Q_{i}$ summarizing the reactive efforts of the butt, the load $d R$ created by filaments lying in the $(i-1)^{\text {th }}$ layer, the load $d R_{1}$ from the filaments lying in $(i+1)^{\text {th }}$ layer and the stress $d P$ arising from the fact that the fiber is under tension. These forces do form a system of converging forces, that can be resolved as to $d Q_{i}$ in a form

$$
d Q_{i}=\frac{d R \sin 60^{\circ}-d P \sin 30^{\circ}}{\cos 30^{\circ}} .
$$

Let we determine the distributed load applied by the filament to its supporting surface, as a distributed load on the bearing surface of the stretched circular ring

$$
q=\frac{T}{k r}
$$

where $r$ - elementary filament axis' radius;

$k$ - number of elementary filaments at the thread.

The load value $d P$ is calculated with respect to $d P=q r d \varphi$ condition. Putting the expression (2) into this formula, we find the load $d P$ as follows:

$$
d P=\frac{T}{k} d \varphi .
$$

Therefore, the admitted tolerances introducing, the $d P$ values does never depend onto the elementary filament radius. There from we conclude:

$$
d R=\frac{T(i-1)}{2 k \cos 30^{\circ}} d \varphi .
$$

Introducing expressions (3), (4) to the equation (1), we can find

$$
d Q_{i}=\frac{T_{i} d \varphi}{2 k \cos 30^{\circ}} .
$$

Then the load applied to a flange by all filaments pertaining to the $i^{\text {th }}$ layer will be: 


$$
Q_{i}=\int_{0}^{2 \pi} \frac{T i d \varphi}{2 k \cos 30^{\circ}}=\frac{\pi i T}{k \cos 30^{\circ}} .
$$

Therefore this load value represents a linear function of layer's order number (layer containing filaments contacting with the butt).

As the expression (5) includes $i=1,3,5, \ldots,(z-3),(z-1)$, then the total force value is

$$
Q=\frac{\pi z^{2} T}{4 k \cos 30^{\circ}}
$$

where $z$ - number of the bobbin's elementary layers.

From equation

$$
\frac{D-d_{1}}{2}=d_{3}\left[(z-1) \cos 30^{\circ}+1\right] \approx z d_{3} \cos 30^{\circ}
$$

we obtain

$$
z=\frac{D-d_{1}}{2 d_{3} \cos 30^{\circ}},
$$

where $D$ - bobbin winding outer diameter;

$d_{1}$ - bobbing shaft outer diameter;

$d_{3}$ - filament cross-section diameter.

The $d_{3}$ value is found from the expression

$$
\frac{\pi d_{3}^{2}}{4} k \gamma N=1
$$

i.e.:

$$
d_{3}=\frac{2}{\sqrt{\pi k \gamma N}}
$$

where $N$ - yarn number;

$\gamma$ - thread material specific weight.

Introducing the $d_{3}$ to the expression (7),

$$
z=\frac{\left(D-d_{1}\right) \sqrt{\pi k \gamma N}}{4 \cos 30^{\circ}} .
$$

We, having put the expression (9) into formula (6) can find

$$
Q=\frac{\pi^{2}\left(D-d_{1}\right)^{2} \gamma N T}{24 \sqrt{3}} .
$$

Apart of axial load $Q$, the bobbin shaft is subject to the winded threads' pressure $p$. Identifying as $q_{\Sigma}$ the distributed load, applied to the bobbin shaft by elementary filament contacting to the shaft we get:

$$
p=\frac{q_{\Sigma}}{d_{3}} .
$$

With respect to admitted assumption of elementary filaments' mutual arrangement at the bobbin

$$
q_{\Sigma}=\sum_{j=1}^{z} q_{j}, \quad(j=1,2, \ldots, z),
$$


where $q_{j}$ - distributed load applied to the bobbin shaft by the $j^{\text {th }}$ counting from the shaft, elementary filaments' layer.

According to the formula (2)

$$
q_{j}=\frac{T}{k\left[\frac{d_{1}}{2}+(j-1) d_{3} \cos 30^{\circ}\right]} .
$$

Introducing the obtained expression for $q_{j}$ into $q_{\Sigma}$ formula,

$$
q_{\Sigma}=\frac{T}{k} \sum_{j=1}^{z} \frac{1}{\frac{d_{1}}{2}-d_{3} \cos 30^{\circ}+j d_{3} \cos 30^{\circ}} .
$$

Due to its insignificant value, we can neglect the second term $\left(d_{3} \cos 30^{\circ}\right)$ and through

$$
\frac{d_{1}}{2}=a ; \quad d_{3} \cos 30^{\circ}=b,
$$

we do obtain:

$$
q_{\sum}=\frac{T}{k} \sum_{j=1}^{z} \frac{1}{a+b j} .
$$

With respect to small value of $b$, the last sum expression can be replaced with an integral

$$
\int_{0}^{z} \frac{d x}{a+b x}=\frac{1}{b} \ln \left(1+\frac{b}{a} z\right)
$$

Then

$$
q_{\Sigma}=\frac{T}{k b} \ln \left(1+\frac{b}{a} z\right) .
$$

Introducing last expression into formula (11), we reach

$$
p=\frac{T}{k b d_{3}} \ln \left(1+\frac{b}{a} z\right) \text {. }
$$

Having reformulated herein the $a, b, d_{3}$ and $z$, expressions, we can definitely find:

$$
p=\frac{z \gamma N T}{2 \sqrt{3}} \ln \frac{D}{d_{1}} .
$$

The bobbin shaft, having a tubular shape, when influenced with $Q$ force and the external pressure $p$, is therefore subjected to pulling stress $\sigma_{p}$ and compression stress $\sigma_{c}$ action:

$$
\sigma_{p}=\frac{4 Q}{\pi\left(d_{1}^{2}-d_{2}^{2}\right)} ; \quad \sigma_{c}=-\frac{2 p d_{1}^{2}}{d_{1}^{2}-d_{2}^{2}} \text {. }
$$

where $d_{2}$ - shaft's inner diameter.

According to the maximum shearing theory, the equivalent stress $\sigma_{e}$ here will be

$$
\sigma_{e}=\sigma_{p}-\sigma_{c}=\frac{2}{d_{1}^{2}-d_{2}^{2}}\left(\frac{2 Q}{\pi}+p d_{1}^{2}\right) \text {. }
$$

Inserting to this expression the values $Q$ and $p$ from formulae (10) and (12), we can find 


$$
\sigma_{e}=\frac{0,3 \gamma d_{1}^{2} N T}{d_{1}^{2}-d_{2}^{2}}\left[\left(\frac{D}{d_{1}}-1\right)+b \ln \frac{D}{d_{1}}\right] .
$$

The equation (13) defines the relationship between the parameters of thread a bobbin, its tension, the shaft design parameters and the winding diameter. This formula allows to determine (at the given bobbin design and the given maximum tolerated stress of its shaft material) the maximum allowable tension of filaments during spool warping.

Having predetermined the warped filaments tension according to formula (13) we can calculate the safe diameter of filament winding onto a spool.

Results. To assess the accuracy of the elementary filaments adopted layout on the spool, considering assumptions made, we can compare the actual $K_{A}$ and theoretical $K_{T}$ numbers of filaments in the bobbin’s longitudinal section for nylon zero-twist complex yarn № 200. This bobbin buttes’ inner side represent the lateral surface of a cone whose generatric line is positioned at an angle $\alpha=8^{\circ} 30^{\prime}$ to the plane perpendicular to the shaft's longitudinal axis. In this case, the $K_{A}$ value is

$$
K_{A}=n m k,
$$

where $n$ - number of bobbin turns while warping;

$m$ - number of treads concurrently winded.

The $K_{T}$ value is found from the condition

$$
K_{T}=\frac{z\left[2 l+\left(D-d_{1}\right) \operatorname{tg} \alpha\right]}{2 d_{3}},
$$

where $l$ - bobbin shaft length.

The $K_{A}$ and $K_{T}$ values are calculated using the obtained expressions (14), (15) at the following parameters (data by the Moscow curtains \& laces manufacturing enterprise): $n=2400 ; m=372$; $k=12 ; l=478 \mathrm{~mm} ; D=305 \mathrm{~mm} ; d_{1}=110 \mathrm{~mm} ; \gamma=1,14 \mathrm{~g} / \mathrm{cm}^{3}$. Parameters $d_{3}$ and $z$ are calculated using (7), (8) formulae.

From calculation effected, $K_{A}=107 \cdot 10^{6}, K_{T}=119 \cdot 10^{6}$. The result error makes approximately $10 \%$, that allows considering the supposed filaments allocation scheme in such corresponding to the real situation.

Conclusions. As a result of the research we elaborated the method of calculating the operating parameters for warp-knitting machines warping bobbins and warping mode:

- The obtained formula allows to determine the relationship between the parameters of thread wound on a warping spool, its tension, shaft diameter structural dimensions and diameter of bobbin winding;

- The formula allows for a given bobbin design with a given allowable stress of the bobbin material to determine the maximum yarn tension in the course of bobbin warping;

- When a predetermined filaments tension during bobbin warping the formula obtained can be used to calculate safe filament winding diameter on the spool.

\section{Література}

1. Піпа, Б.Ф. Динаміка приводу основов'язальних машин / Б.Ф. Піпа, В.В. Чабан // Вісн. Хмельниц. нац. ун-ту. Техн. науки. - 2007. - № 6. - С. 11-14.

2. Чабан, В.В. Динаміка основов’язальних машин: монографія / В.В. Чабан, Л.А. Бакан, Б.Ф. Піпа ; Київ. нац. ун-т технологій та дизайну. - К.: КНУТД, 2012. — 286 с.

3. Чабан, В.В. Наукові основи проектування механізмів нормалізації процесу відтяжки полотна на основов'язальних машинах: монографія / В.В. Чабан, Т.В. Іваненко, Б.Ф. Піпа; МОНМС України, Київ. нац. ун-т технологій та дизайну. - К.: КНУТД, 2012. — 157 с. 
4. Чабан, В.В. Динаміка приводу основов'язальної машини типу ОВ / В.В. Чабан // Вісн. Хмельниц. нац. ун-ту. Техн. науки. - 2011. - № 4. - С. $22-25$.

5. Чабан, В.В. Динаміка основов'язальної машини 3 відцентровою фрикційною муфтою / В.В. Чабан, Б.Ф. Піпа // Вісн. Хмельниц. нац. ун-ту. Техн. науки. — 2012. - № 2. — С. $10-16$.

6. Чабан, В.В.Вплив режиму пуску основов'язальної машини на динамічні навантаження / В.В. Чабан, Б.Ф. Піпа // Вісн. Хмельниц. нац. ун-ту. Техн. науки. - 2012. - № 3. - С. $20-24$.

7. Чабан, В.В. Вплив фізико-механічних властивостей ниток основи на зміну їх натягу в зоні в'язання основов'язальної машини / В.В. Чабан // Пробл. легкої і текстильної пром-сті України. - 2012. - № 1(19). - С. $88-92$.

8. Чабан, В.В. Вплив натягу ниток основи на їх пластичну деформацію / В.В. Чабан // Вісн. Хмельниц. нац. ун-ту. Техн. науки. - 2012. - № 4. - С. $12-15$.

9. Чабан, В.В. Оптимізація перехідного процесу при пуску основов’язальної машини / В.В. Чабан, Б.Ф. Піпа // Вісн. Хмельниц. нац. ун-ту. Техн. науки. - 2012. - № 5. - С. 22 - 25.

10. Чабан, В.В. Динаміка пуску основов'язальної машини при попередньому напруженні в'язей привода / В.В. Чабан, Б.Ф. Піпа // Вісн. Черніг. держ. технолог. ун-ту. Техн. науки. — 2012. № 4(61). - С. $35-39$.

11. Чабан, В.В. Повышение эффективности работы привода основовязальной машины / В.В. Чабан, Б.Ф. Пипа // Дизайн и технологии. - 2012. — № 32(74). — С. $107-110$.

12. Чабан, В.В. Особливості проектування механізму накатування основов'язального полотна 3 постійним моментом / В.В. Чабан, Б.Ф. Піпа // Вісн. Київ. нац. ун-ту технологій та дизайну. 2013. — № 1(69). — С. $97-100$.

13. Чабан, В.В. Анализ подходов к расчету высокочастотного стабилизатора динамического натяжения нитей основы / В.В. Чабан // Дизайн. Материалы. Технологии. — 2013. — № 1(26). — С. 45 - 49.

14. Чабан, В.В. Напружено-деформований стан основов'язального полотна у рулоні / В.В. Чабан, О.Ю. Олійник // Вісн. Хмельниц. нац. ун-ту. Техн. науки. - 2013. - № 2. - С. $49-52$.

15. Chaban, V. Influence of plastic deformation warp thread on basic physical and mechanical data warpknitting fabrics / V. Chaban // Vlákna a textil. — 2013. — No. 1. — PP. $9-13$.

\section{References}

1. Pipa, B.F. and Chaban, V.V. (2007). Drive dynamics of warp-knitting machines. Herald of Khmelnytskyi national university: Technical sciences, 6, 11-14.

2. Chaban, V.V., Bakan, L.A. and Pipa, B.F. (2012). Dynamics of Warp-Knitting Machines. Kyiv: Kyiv National University of Technologies and Design.

3. Chaban, V.V., Ivanenko, T.V. and Pipa, B.F. (2011). Scientific Fundamentals of Designing Mechanisms of Canvas Guyed Process Normalization for Warp-Knitting Machines. Kyiv: Kyiv National University of Technologies and Design.

4. Chaban, V.V. (2011). Drive dynamics of OV-type warp-knitting machines. Herald of Khmelnytskyi national university: Technical sciences, 4, 22-25.

5. Chaban, V.V. and Pipa, B.F. (2012). Dynamic of warp-knitting machine with centrifugal friction clutch. Herald of Khmelnytskyi national university: Technical sciences, 2, 10-16.

6. Chaban, V.V. and Pipa, B.F. (2012). Influence of the mode of starting of knitting machine on the dynamic loading. Herald of Khmelnytskyi national university: Technical sciences, 3, 20-24.

7. Chaban, V.V. (2012). Effect of physical and mechanical properties of warp threads on the change of their tension in area of knitting of warp-knitting machine. Problems of Light and Textile Industry of Ukraine, 1, 88-92.

8. Chaban, V.V. (2012). Effect the warp threads tension on their plastic deformation. Herald of Khmelnytskyi national university: Technical sciences, 4, 12-15.

9. Chaban, V.V. and Pipa, B.F. (2012). Optimization of the transition process at start of warp-knitting machine. Herald of Khmelnytskyi national university: Technical sciences, 5, 22-25.

10. Chaban, V.V. and Pipa, B.F. (2012). Dynamics of starting of warp-knitting machine in the previous tension of ligature of drive. Visnyk of Chernihiv State Technological University: Technical Sciences, 4, 35-39.

11. Chaban, V.V. and Pipa, B.F. (2012). Increasing efficiency of the warp-knitting machine drive. Design and Technology, 32, 107-110.

12. Chaban, V. and Pipa, B. (2013). Features of the projection mechanism of rolling warp-knitting fabric with permanent moment. Bulletin of the Kyiv National University of Technologies and Design, 1, 97-100. 
13. Chaban, V.V. (2013). Analysis of approaches to the calculation of the high-frequency stabilizer of dynamic tension of warp threads. Design. Materials. Technology, 1, 45-49.

14. Chaban, V.V. and Oliynyk, O.Y. (2013). Tensely strained condition of the fabric, even at formation big diameter rolls, that is actual for increasing productivity of machine. Herald of Khmelnytskyi national university: Technical sciences, 2, 49-53.

15. Chaban, V. (2013). Influence of plastic deformation warp thread on basic physical and mechanical data warp-knitting fabrics. Fibres and Textiles, 1, 9-13.

\section{АНОТАЦІЯ / АННОТАЦИЯ / ABSTRACT}

В.В. Чабан, Б. Ф. Піпа. Розрахунок снувальних котушок основов'язальних машин. Стаття присвячена розвитку наукових основ проектування в'язальних машин, зокрема розрахунку снувальних котушок основов'язальних машин. Запропоновано метод розрахунку робочих параметрів снувальних котушок та режиму снування. Одержана формула, що дозволяє визначити взаємозв'язки між параметрами намотуваних на снувальну котушку ниток, їх натягом, конструктивними розмірами ствола котушки і діаметром намотки котушки. Запропонована формула дозволяє при заданій конструкції котушки і заданому допустимому напруженні матеріалу іiі ствола визначити максимально допустимий натяг ниток в процесі їх снування на котушку. При заданому натягу ниток під час снування по одержаній формулі може бути розрахований безпечний діаметр намотування ниток на котушку.

Ключові слова: основов'язальна машина, снувальна котушка, синтетичні нитки, робочі параметри снувальної котушки, напруження в снувальній котушці.

В.В. Чабан, Б.Ф. Пипа. Расчет сновальных катушек основовязальных машин. Статья посвящена развитию научных основ проектирования вязальных машин, в частности расчету сновальных катушек основовязальных машин. Предложен метод расчета рабочих параметров сновальных катушек и режима сновки. Получена формула, позволяющая определить взаимосвязи между параметрами наматываемых на сновальную катушку нитей, их натяжением, конструктивными размерами ствола катушки и диаметром намотки катушки. Предложенная формула позволяет при заданной конструкции катушки и заданном допустимом напряжении материала ее ствола определить максимально допустимое натяжение нитей в процессе их сновки на катушку. При заданном натяжении нитей во время сновки по полученной формуле может быть рассчитан безопасный диаметр наматывания нитей на катушку.

Ключевые слова: основовязальная машина, сновальная катушка, синтетические нити, рабочие параметры сновальной катушки, напряжения в сновальной катушке.

V.V. Chaban, B.F. Pipa. The calculation of warping spools of warp-knitting machines. The paper is devoted to the development of scientific bases of the knitting machine design, in particular, to the calculation of warping spools of warpknitting machines. The method of calculating the operating parameters of warping spools and mode of winding is offered. A formula that is obtained allows to define relationship between the parameters of the threads wound on a warping spool, their pull, structural dimensions of spool barrel and the diameter of spooling. With the given spool design and the given value of permissible tension of the material of its barrel, the offered formula allows to determine the maximum tension of the threads in the process of their winding on a spool. By this formula the safe diameter of winding the threads onto the spool can be calculated at a given pull of the threads during winding.

Keywords: warp-knitting machine, warping spool, synthetic threads, operating parameters of warping spool, tensions in a warping spool.

Reviewer Dr. techn. sciences, Prof. Odesa nat. polytechnic univ. Suryaninov M.G.

Received June 8, 2014 